\title{
PENDUGAAN PENYEBARAN PENYAKIT DEMAM BERDARAH DENGUE (DBD) DI KOTA PADANG
}

\author{
SITI JURIAH, FERRA YANUAR, HAZMIRA YOZZA \\ Program Studi S1 Matematika, \\ Fakultas Matematika dan Ilmu Pengetahuan Alam, Universitas Andalas, \\ Kampus UNAND Limau Manis Padang, Indonesia. \\ email : Sitijuriah1506@gmail.com
}

Diterima 9 Maret 2019 Direvisi 7 April 2019 Dipublikasikan 7 Mei 2019

\begin{abstract}
Abstrak. Demam Berdarah Dengue (DBD) merupakan suatu penyakit menular yang selalu menjadi salah satu masalah utama kesehatan masyarakat Indonesia. DBD ditularkan melalui gigitan nyamuk Aedes Aegypti. Penyakit DBD merupakan suatu penyakit endemik, yang jumlah penderita dan luas penyebarannya akan semakin bertambah seiring meningkatnya mobilitas dan kepadatan penduduk. Pada penelitian ini dilakukan pendugaan risiko relatif penyebaran penyakit DBD di kota Padang. Pendugaan dilakukan dengan menggunakan metode Penduga Kemungkinan Maksimum (Maximum Likelihood Estimation). Untuk setiap kecamatan di kota padang rata-rata tingkat risiko relatif penyebaran penyakit DBD hampir sama yaitu berada pada interval sedang dan rendah.
\end{abstract}

Kata Kunci: DBD, Poisson, Penduga Kemungkinan Maksimum

\section{Pendahuluan}

Penyakit DBD masih merupakan salah satu masalah kesehatan masyarakat yang utama di Indonesia. Demam Berdarah adalah penyakit yang disebabkan oleh virus Dengue dan ditularkan oleh nyamuk Aedes aegypti. Penyakit DBD merupakan suatu penyakit endemik, yang jumlah penderita dan luas penyebarannya akan semakin bertambah seiring meningkatnya moblitas dan kepadatan penduduk. Penyakit ini selalu ditemukan setiap tahun, sehingga jika tidak ditangani dengan serius maka akan memakan banyak korban jiwa. Oleh sebab itu, perlu dibuat pemetaan penyakit DBD tersebut, sehingga penanggulangannya dapat dilakukan dengan lebih efektif. Pemetaan tersebut dapat dilakukan berdasarkan nilai risiko relatif munculnya kejadian DBD di area tersebut.

Salah satu metode yang dapat digunakan untuk menduga tingkat risiko relatif penyebaran DBD ini adalah dengan menggunakan Penduga Kemungkuninan Maksimum (Maximum Likelihood Estimation). Data penyakit biasanya berupa data cacahan, sehingga data penyakit ini sering diasumsikan berdistribusi Poisson 


\section{Landasan Teori}

\subsection{Distribusi Poisson}

Percobaan yang terjadi pada suatu selang waktu tertentu atau di suatu daerah tertentu sering disebut percobaan Poisson.

Definisi 2.1. [4] Sebaran peluang bagi suatu peubah acak Poisson X yang menyatakan banyaknya hasil percobaan yang terjadi pada suatu selang waktu atau daerah tertentu, adalah

$$
f(x, \tau)=\frac{\left(e^{-\tau}\right) \tau^{x}}{x !}, x=1,2, \cdots, \tau>0,
$$

dalam hal ini $\tau$ adalah rata-rata banyak hasil percobaan yang terjadi selama selang waktu atau daerah yang dinyatakan, dan $e=2,71828 \cdots$.

\subsection{Penduga Kemungkinan Maksimum}

Definisi 2.2. [1] Fungsi kepekatan peluang bersama dari $n$ peubah acak $X_{1}, X_{2}, \cdots, X_{n}$ yang dihitung pada $x_{1}, x_{2}, \cdots, x_{n}$ yaitu $f\left(x_{1}, x_{2}, \cdots, x_{n} ; \tau\right)$, adalah menyatakan suatu fungsi likelihood. Untuk $x_{1}, x_{2}, \cdots, x_{n}$ yang ditetapkan, maka fungsi likelihood dari $\tau$ dinotasikan oleh $L(\tau)$. Jika $X_{1}, X_{2}, \cdots, X_{n}$ menyatakan suatu contoh acak dari $f\left(x_{n} ; \tau\right)$, maka:

$$
\begin{aligned}
L(\tau) & =f\left(x_{1} ; \tau\right) \times f\left(x_{2} ; \tau\right) \times \cdots \times f\left(x_{n} ; \tau\right) \\
& =\prod_{i=1}^{n} f\left(x_{i} ; \tau\right)
\end{aligned}
$$

Definisi 2.3. [1] Misalkan $L(\tau)=f\left(x_{1}, x_{2}, \cdots, x_{n} ; \tau\right), \tau \in \omega$ adalah fkp brsama dari $X_{1}, X_{2}, \cdots, X_{n}$. Untuk suatu himpunan dari pengamatan $\left(X_{1}, X_{2}, \cdots, X_{n}\right)$, nilai $\hat{\tau}$ pada $\omega$ yang dinyatakan dalam $L(\tau)$ adalah maksimum yang disebut sebagai penduga kemungkinan maksimum (PKM) dari $\tau$, dengan $\hat{\tau}$ adalah nilai dari $\tau$ yang memenuhi

$$
f\left(x_{1}, x_{2}, \cdots, x_{n} ; \hat{\tau}\right)=\max _{\tau \in \omega} f\left(x_{1}, x_{2}, \cdots, x_{n}\right)
$$

\section{Pembahasan}

\subsection{Deskripsi Peubah yang Digunakan}

Data yang digunakan pada penelitian ini disajikan pada Tabel 1 dan deskripsi dari peubah respon untuk pendugaan penyakit DBD di Kota Padang dapat dilihat pada Gambar 1.

Berdasarkan Gambar 1 dapat dilihat bahwa distribusi jumlah kasus penderita penyakit DBD tertinggi pada tahun 2017 di Kota Padang terjadi di Kecamatan Kuranji dan Koto Tangah yaitu sebesar 140 kasus, dan yang terendah terjadi pada Kecamatan Bungus dengan 15 kasus. Tingginya jumlah kasus penderita penyakit DBD pada suatu daerah dapat terjadi dikarenakan masih banyaknya masyarakat yang tidak sadar dan tidak peduli terhadap lingkungannya. Misalkan, masih banyaknya genangan-genangan air yang akan menyebabkan cepatnya perkembangan jentik nyamuk. 
Tabel 1. Data Penderita DBD di Kota Padang Tahun 2017

\begin{tabular}{|c|c|c|}
\hline Kecamatan & $Y_{i}$ & $e_{i}$ \\
\hline Padang Barat & 18 & 31.680 \\
\hline Padang Timur & 48 & 55.638 \\
\hline Padang Utara & 28 & 49.680 \\
\hline Padang Selatan & 21 & 41.531 \\
\hline Koto Tangah & 140 & 119.240 \\
\hline Nanggalo & 34 & 41.592 \\
\hline Kuranji & 140 & 93.580 \\
\hline Pauh & 70 & 44.154 \\
\hline Lubuk Kilangan & 29 & 35.937 \\
\hline Lubuk Begalung & 65 & 78.257 \\
\hline Bungus & 15 & 16.721 \\
\hline
\end{tabular}

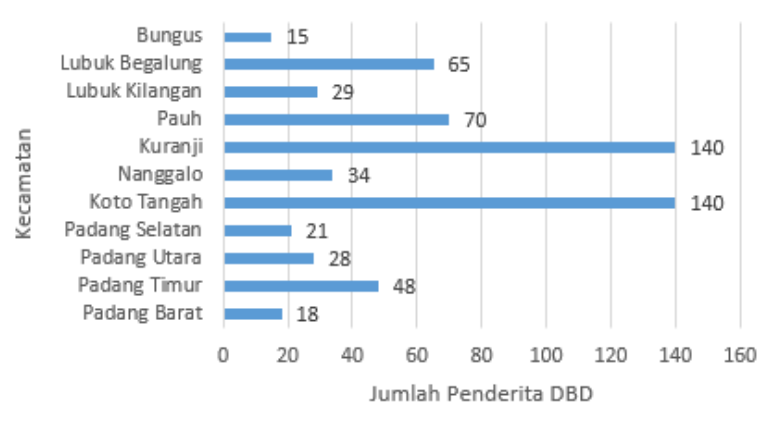

Gambar 1. Diagram Batang Jumlah Penderita Penyakit DBD di Kota Padang

\subsection{Pendugaan Penyakit DBD dengan Penduga Kemungkinan Maksimum}

Misalkan $Y_{i}$ yang merupakan banyaknya kasus penyakit di area ke- $i$ diasumsikan berdistribusi Poisson $\left(-e_{i} \tau_{i}\right)$, fkp dari Poisson adalah sebagai berikut

$$
f\left(y_{i} \mid \tau_{i}\right)=\frac{\exp \left(-e_{i} \tau_{i}\right)\left(-e_{i} \tau_{i}\right)_{i}^{y}}{y_{i} !}
$$

Dengan demikian, fungsi kemungkinan dinyatakan dengan

$$
f\left(\tau_{i} \mid y_{i}\right)=f\left(y_{i} \mid \tau_{i}\right)=\frac{\exp \left(-e_{i} \tau_{i}\right)\left(-e_{i} \tau_{i}\right)_{i}^{y}}{y_{i} !} .
$$

Logaritma dari fungsi $L\left(\tau_{i} y_{i}\right)$ adalah

$$
\ln L\left(\tau_{i} \mid y_{i}\right)=\ln \left(\frac{\exp \left(-e_{i} \tau_{i}\right)\left(-e_{i} \tau_{i}\right)_{i}^{y}}{y_{i} !}\right)-e_{i} \tau_{i}+y_{i} \ln \left(e_{i} \tau_{i}\right)-\ln y_{i} !
$$


Penduga kemungkinan maksimum diperoleh dengan cara berikut:

$$
\begin{aligned}
\frac{d}{d \tau_{i}} \ln L\left(\tau_{i} \mid y_{i}\right)=0, & \Longleftrightarrow-e_{i}+\frac{y_{i} e_{i}}{e_{i} \tau_{i}}=0, \\
& \Longrightarrow \hat{\tau}_{i}=\frac{y_{i}}{e_{i}} .
\end{aligned}
$$

Jadi, $\hat{\tau}_{i}=\frac{y_{i}}{e_{i}}$ penduga langsung bagi $\tau_{i}$, dengan $y_{i}$ dan $e_{i}$ masing-masing menyatakan banyaknya pengamatan dan nilai harapan dari kasus pada periode ke- $i$, untuk $i=$ $1,2, \cdots, m$, dengan nilai $e_{i}$ dihitung dengan cara sebagai berikut:

$$
e_{i}=n_{i}\left(\frac{\Sigma_{i} y_{i}}{\Sigma_{i} n_{i}}\right) .
$$

Penduga risiko relatif yang merupakan penduga kemungkinan maksimum bagi $\tau_{i}$ yaitu $\hat{\tau}_{i}=\frac{y_{i}}{e_{i}}$ merupakan penduga tak bias. Hal ini dapat ditunjukkan dengan cara memperlihatkan bahwa nilai harapan penduga parameternya sama dengan parameternya [3], sebagaimana diperlihatkan pada uraian berikut:

$$
E\left(Y_{i}\right)=e_{i} \tau_{i} .
$$

Jadi,

$$
E\left(\hat{\tau}_{i}\right)=E\left(\frac{Y_{i}}{e_{i}}\right)=\frac{1}{e_{i}} E\left(Y_{i}\right)=\frac{1}{e_{i}} \tau_{i}=\tau_{i} .
$$

Penduga bagi $\tau_{i}$ yaitu $\hat{\tau}_{i}=\frac{y_{i}}{e_{i}}$ terbukti merupakan penduga yang bersifat tak bias, karena $E\left(\hat{\tau}_{i}\right)=\tau_{i}$.

Karena nilai harapan dan ragam dari distribusi Poisson adalah sama, maka nilai ragam dari $\tau_{i}$ dapat diperoleh sebagai berikut:

$$
\operatorname{Var}\left(\hat{\tau}_{i}\right)=\operatorname{Var}\left(\frac{Y_{i}}{e_{i}}\right)=\frac{1}{e_{i}^{2}} \operatorname{Var}\left(Y_{i}\right)=\frac{1}{e_{i}^{2}}\left(e_{i} \tau_{i}\right)=\frac{\tau_{i}}{e_{i}} .
$$

Tingkat nilai risiko relatif penyebaran penyakit DBD dapat dibagi menjadi lima kategori, yaitu [5]:

1. Sangat rendah : $0,000-0,499$.

2. Rendah : $0,500-0,999$.

3. Sedang : $1,000-1,499$.

4. Tinggi : $1,500-1,999$.

5. Sangat tinggi $: \geq 2,000$.

Berdasarkan Tabel 2 di atas dapat dilihat nilai dugaan risiko penyebaran penyakit DBD untuk setiap kecamatan di Kota Padang. Dapat dilihat bahwa kecamatan Pauh memiliki tingkat risiko yang paling tinggi diantara kecamatankecamatan lainnya di Kota Padang, yaitu dengan nilai risiko 1,56. Kemudian diikuti dengan kecamatan Kuranji dan Koto tangah dengan nilai risiko 1, 50 dan 1, 17. Sedangkan tingkat risiko yang paling rendah berada di kecamatan Padang Selatan dengan nilai risiko 0,51 . 
Tabel 2. Nilai Dugaan Risiko Relatif Penyakit DBD di Kota Padang

\begin{tabular}{|c|c|c|}
\hline Kecamatan & Risiko Relatif & Standar error \\
\hline Padang Barat & 0.568 & 0,018 \\
\hline Padang Timur & 0.863 & 0.016 \\
\hline Padang Utara & 0.563 & 0.011 \\
\hline Padang Selatan & 0.506 & 0.012 \\
\hline Koto Tangah & 1.174 & 0.010 \\
\hline Nanggalo & 0.817 & 0.020 \\
\hline Kuranji & 1.496 & 0.016 \\
\hline Pauh & 1.586 & 0.036 \\
\hline Lubuk Kilangan & 0.807 & 0.022 \\
\hline Lubuk Begalung & 0.831 & 0.011 \\
\hline Bungus & 0.897 & 0.054 \\
\hline
\end{tabular}

\section{Kesimpulan}

Penyebaran penyakit DBD untuk setiap kecamatan di Kota Padang rata-rata berada pada tingkat risiko hampir sama yaitu berada pada tingkat risiko rendah dengan skala 0,500-0,999 dan sedang dengan skala 1,000 - 1,499. Hal ini dapat dikatakan bahwa masyarakat dan pemerintah sudah semakin sadar akan linkungannya.

\section{Daftar Pustaka}

[1] Bain, L.J., Engelhard, M. 1992. Introduction to Probability and Mathematical Statistic, Edisi ke-2, Duxbury Press, California

[2] Dinas Kesehatan Kota Padang 2017. Profil Kesehatan Kota Padang Tahun 2017. Diakses tanggal 20 November 2018.

[3] Kismiantini., 2007, Pendekatan Bayes Empirik pada Pendugaan Statistik Area Kecil Berbasis Model Poisson-Gamma dengan Peubah Penyerta, Seminar Nasional MIPA, M (4): $75-92$

[4] Walpole, R.E., 1995, Pengantar Statistika Edisi Ketiga, Pustaka Utama, Jakarta

[5] Yong, B., Kristiani, F., Irawan, R., 2016, Analisi Risiko Relatif Penyebaran Penyakit Demam Dengue di Kota Bandung Menggunakan Model Poisson:Studi Kasus Data RS Santo Borromeus, CR Journal, 02(01): 39 - 54 